\title{
Observations of carbon-nitrogen manipulation and periphyton growth stimulation on fish farming in an integrated intensive-extensive aquaculture system
}

\author{
Ludmiła Kolek, Maciej Pilarczyk, Michał Inglot, Bartłomiej Stonawski, Joanna Szczygieł
}

Received - O6 March 2018/Accepted - 12 December 2019. Published online: 31 December 2019; Inland Fisheries Institute in Olsztyn, Poland Citation: Kolek L., Pilarczyk M., Inglot M., Stonawski B., Szczygieł J. 2019 - Observations of carbon-nitrogen manipulation and periphyton growth stimulation on fish farming in an integrated intensive-extensive aquaculture system - Fish. Aquat. Life 27: 169-177.

\begin{abstract}
The results of observations of intensive sturgeon production integrated with an extensive earthen fish pond are described. The main objective of the study was to show how technological modifications applied to enhance nitrogen assimilation in ponds and nutrient retention in aquaculture products influenced fish production. Each of two integrated systems, A and B, consisted of four intensive fish tanks stocked with sturgeon and one extensive carp pond stocked with carp (Cyprinus carpio L.), silver carp (Hypophthalmichthys molitrix (Val.)) and common nase (Chondrostoma nasus L.). The fish tanks were supplied with water from the extensive pond and the effluent from the tanks was discharged into the same pond, which acted as a biological filter for fish production. System B pond was supplemented with carbohydrates (methanol) and plastic substrates for periphyton development that were installed to increase nutrient utilization. The results of the observations showed better water quality and higher fish production in pond $\mathrm{B}$, but no differences were noted in sturgeon growth performance in system A. The combination of these modifications appeared to be an efficient way of increasing nutrient retention and improving water quality.
\end{abstract}

Keywords: extensive carp production, integrated aquaculture systems, intensive sturgeon production, nutrient retention, wastewater utilization

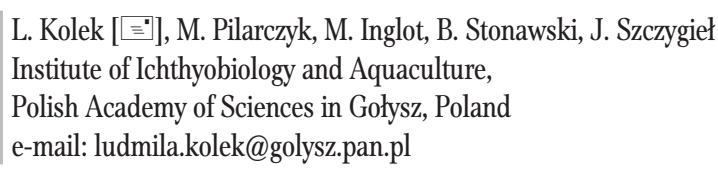

\section{Introduction}

The growth of intensive aquaculture production in recent years and the related problem of ensuring that discharged waters are of adequate quality have prompted the search for alternative waste disposal methods. The most widely operated type of intensive fish production systems are based on animals from one trophic level, and most often these are predatory fish. In these systems, nutrient retention in fish biomass is low at only about $20-30 \%$ of the feed consumed (Hargraves 1998, Avnimelech 1999, Brune et al. 2003, Schneider et al 2005). This can be improved by coupling intensive and extensive aquaculture. Unconsumed feed, feces, and waste products negatively affect rearing conditions in intensive aquaculture, and these must be disposed of outside the system. However, in sufficient quantities, these same substances can be the basis for the development of primary and secondary producers that are responsible for the productivity of extensive fish ponds, and, thus, for fish biomass yields (Kestemont 1995, Liu and Cai 1998). The main goal of integrating intensive and extensive fish production should be to increase nutrient retention within a single system through the production of organisms comprising the

\footnotetext{
(c) Copyright by Stanisław Sakowicz Inland Fisheries Institute in Olsztyn.

(C) 2019 Author(s). This is an open access article licensed under the Creative Commons Attribution-NonCommercial-NoDerivs License (http://creativecommons.org/licenses/by-nc-nd/3.0/).
} 
largest possible share of the ecosystem's trophic web. Although integrated intensive-extensive aquaculture systems have already proven to be profitable, especially in tropical climate zones, there are ways to further enhance their nutrient retention. One such approach is to apply additional substrate to promote the growth of periphyton (i.e., the complex of attached biota, including associated detritus and microorganisms) that can be a source of food for fish or other organisms (Azim et al. 2001, 2002, 2003a, 2003b, Gal et al. 2010).

Earthen carp ponds are known for their trophic complexity and efficiency that facilitates significant contributions of natural food to fish biomass. However, such integrated systems receive large amounts of waste during operation, including toxic nitrogenous species $\left(\mathrm{NH}_{4}{ }^{+}\right.$and $\left.\mathrm{NO}_{2}{ }^{-}\right)$. One of the strategies to remove excessive nitrogen is to enhance its assimilation into microbial proteins by providing a source of organic carbon to the system (Avnimelech et al. 1994, Avnimelech 1999, Crab et al. 2007, Asaduzzaman et al. 2008). In this paper we describe the results of observations of intensive fish production integrated with an extensive earthen fish pond. The intensive unit was based on Siberian sturgeon (Acipenser baerii Brandt) and its hybrid with Russian sturgeon (Acipenser gueldenstaedtii Brandt \& Ratzeburg), which are the best suited sturgeon species for Central European climatic conditions and provide high quality meat that is in consumer demand (Steffens et al. 1990). The objective of monitoring was to show how the treatments applied for controlling inorganic nitrogen and enhancing nutrient retention influenced fish production.

\section{Materials and methods}

The investigation was conducted in southern Poland (4952'14.4”N $18^{\circ} 47^{\prime} 47.1^{\prime}$ E) where climatic conditions are moderate. We observed two integrated systems, each of which was composed of an intensive and an extensive subsystem. Each of the intensive subsystems was comprised of four identical detached
$10 \mathrm{~m}^{3}$ fish tanks. These tanks were located on the banks of earthen ponds, each approximately $0.18 \mathrm{ha}$, that were the extensive subsystems. System A consisted of tanks 1 to 4 and pond A, and system B consisted of tanks 5 to 8 and pond B (Fig. 1). Separate electric pumps were used to supply each tank with water from the extensive ponds at a withdrawal rate

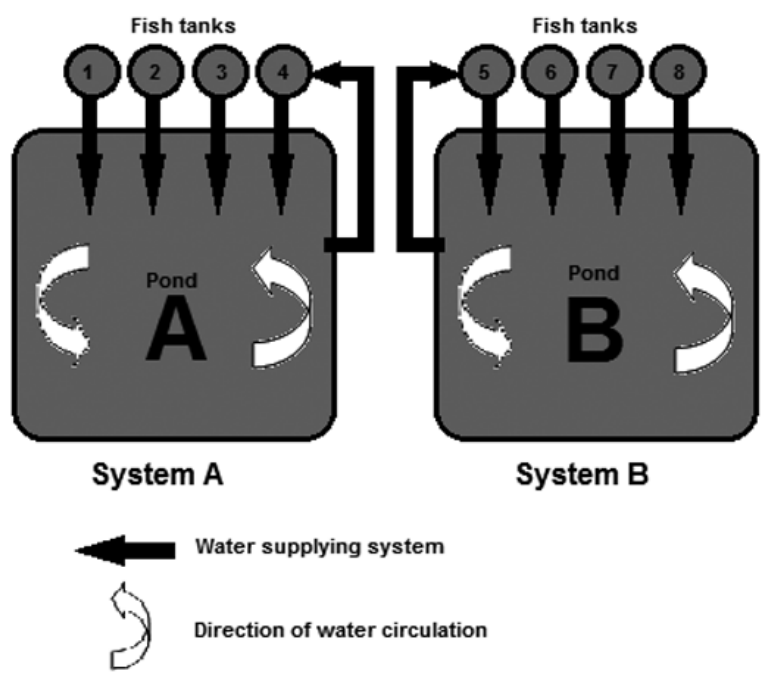

Figure 1. Setup of the integrated systems.

of $25 \mathrm{~m}^{3} \cdot \mathrm{h}^{-1}$, thereby ensuring $25-30 \%$ water volume exchange from each fish tank per hour. Tank effluent was discharged gravitationally back into the same ponds. The tanks were aerated with fine bubble diffusers connected to a side channel blower. Paddle aerators were used in the extensive ponds to provide additional aeration and water circulation. These cycled through a regime of $1 \mathrm{~h}$ on followed by $1 \mathrm{~h}$ off to provide sufficient aeration and optimal electricity consumption.

Throughout the production season, ammonia nitrogen was measured twice weekly (modified Clesceri et al. 1998), and $\mathrm{pH}$, dissolved oxygen, and water temperature were measured three times weekly (MultiLine P3 with OxiCal-SL and SenTIx 41 electrodes, WTW, Germany) in both ponds and all the tanks. Pond water was further sampled weekly (on one of the above sampling days) for measurements of total Kjeldahl nitrogen (TKN; Kjeldahl method), nitrate (PN-82 C-01576/08), nitrite (Hermanowicz et al. 1976), total phosphorus (TP), 
and phosphates (PN - EN ISO 6878). Water quality was assumed to be homogeneous throughout each pond's surface are thanks to the paddle aerators deployed in each pond. Water samples were collected and measurements were conducted in the morning, between 08:00 and 09:00.

Modifications aimed at increasing nutrient assimilation were applied in pond B. Sections of plastic substrate $80 \mathrm{~cm}$ in length were attached to ropes and stretched out across the pond to serve as additional substrate for periphyton development. A total of 650 linear meters was installed, which corresponded to about $240 \mathrm{~m}^{2}$ of substrate for periphyton growth. In order to stimulate bacterioplankton development, and hence nitrogen, $1 \mathrm{~L}$ of methanol (99.8\%) was added directly to the pond for every $\mathrm{kg}$ of feed used in the intensive subsystem. The amount of carbohydrate supplementation was evaluated based on published data and was the theoretical stoichiometric $\mathrm{C} / \mathrm{N}$ proportion in bacterial cells taking into account the nitrogen load introduced with the feed and the ammonia concentration in the pond water (Avnimelech et al. 1994, Avnimelech 1999, Playchoom et al. 2011).

Four of the tanks $(3,4,7$, and 8$)$ were stocked with 1-year-old Siberian sturgeon of a mean weight of $310( \pm 44.5) \mathrm{g}$, and the other four tanks $(1,2,5$, and 6) were stocked with hybrid (Russian x Siberian) sturgeon fry of a mean weight of $14.8( \pm 0.4) \mathrm{g}$. The stocking density in the tanks of both systems was equal; therefore, it was assumed that both ponds received equal nutrient loads. Tank stocking is detailed in Table 1. The number of sturgeon and their mean body weight $(n=30)$ were recorded for every tank on the day of stocking, every three weeks during the 156-day growing season (May - October), and at final harvest. The sturgeon were fed Aller Aqua Bronze (Aller Aqua, Poland). Feeding rates were adjusted after every weighing to compensate for weight gain and were maintained at about $2 \%$ of body weight, but not lower than $1.8 \%$. All the tanks were subjected to the same feeding regime.

Each pond was stocked with 227 individuals of common carp (Cyprinus carpio L.) with a cumulative weight of $82.5 \mathrm{~kg}$ and $81.2 \mathrm{~kg}$ in ponds $\mathrm{A}$ and $\mathrm{B}$, respectively, 39 specimens of silver carp (Hypophthalmichthys molitrix) with a cumulative weight of $45 \mathrm{~kg}$ (pond A) and $48 \mathrm{~kg}$ (pond B), and 1,000 specimens of common nase (Chondrostoma nasus L.) with a cumulative weight of $10 \mathrm{~kg}$ (see Table 1 for details). These fish were only counted and measured on the day of stocking and at the end of the experiment because catching fish at other times would have required suspending water exchange between the ponds and the tanks, thereby risking the loss of sturgeon from poor water conditions. No supplemental feed was supplied to the ponds. Feed conversion ratios (FCR), specific growth rates (SGR), and body weight gain were calculated.

\section{Results}

The basic hydrochemical parameters were similar for both of the systems and did not exceed levels that were harmful to the fish (Table 2). Average seasonal values of ammonia nitrogen, nitrite, nitrate, TKN, total phosphorus, and phosphates (Table 2) differed between the two systems. Chlorophyll content in the pond water is shown in Fig. 2. The final average body weight per sturgeon fry was $419( \pm 18.8) \mathrm{g}$. The mean body weight of sturgeon yearlings was 1,800 $( \pm 149.5) \mathrm{g}$ per fish. Data on fish yields and the growth performance in the intensive units are summarized in Table 1.

At the beginning of the season (days 1-32), the sturgeon yearling SGR was $1.39 \%$ in system A and $1.28 \%$ in system B. Over time, the SGR decreased, and the average seasonal values were $0.65 \%$ and $0.56 \%$ in systems A and B, respectively. The fish fry growth rates were very high at the beginning and in the middle of the rearing season (days 32-105). The average SGR at this time was $2.6 \%$ in both the A and B systems. That sturgeon fry SGR values did not drop significantly when water temperatures were high (days 58-84) and in excess of $23^{\circ} \mathrm{C}$ is noteworthy. The FCR for fish fry ranged from 0.72 to 0.85 in different tanks. The average FCR for all the tanks with fish fry was 0.8 . The FCR for yearling fish was high at 
Table 1

Characteristic of fish stocking and harvesting

\begin{tabular}{|c|c|c|c|c|c|c|c|c|c|}
\hline & & \multicolumn{4}{|l|}{ System A } & \multicolumn{4}{|l|}{ System B } \\
\hline & & Tank 1 & Tank 2 & Tank 3 & Tank 4 & Tank 5 & Tank 6 & Tank 7 & Tank 8 \\
\hline \multirow{4}{*}{$\begin{array}{l}\text { Stocked } \\
\text { fish }\end{array}$} & Number of fish & 374 & 374 & 250 & 250 & 374 & 374 & 250 & 250 \\
\hline & $\begin{array}{l}\text { Mean fish } \\
\text { weight (g) }\end{array}$ & $15.1 \pm 3.6$ & $14.2 \pm 4$ & $477.8 \pm 110$ & $458.8 \pm 92$ & $14.8 \pm 4.39$ & $15.2 \pm 3.09$ & $456.9 \pm 64$ & $484.4 \pm 96$ \\
\hline & $\begin{array}{l}\text { Tank biomass } \\
(\mathrm{kg})\end{array}$ & 5.65 & 5.31 & 119.5 & 114.7 & 5.54 & 5.68 & 114.2 & 121.1 \\
\hline & $\begin{array}{l}\text { Subsystem } \\
\text { biomass (kg) }\end{array}$ & 245.16 & & & & 246.52 & & & \\
\hline Harvested & Number of fish & 337 & 305 & 250 & 247 & 328 & 311 & 234 & 243 \\
\hline \multirow[t]{6}{*}{ fish } & Survival (\%) & 90 & 82 & 100 & 99 & 88 & 83 & 94 & 97 \\
\hline & $\begin{array}{l}\text { Mean fish } \\
\text { weight (g) }\end{array}$ & $212.9 \pm 94$ & $218 \pm 98$ & $870 \pm 320$ & $880 \pm 299$ & $238.5 \pm 63$ & $213.5 \pm 82$ & $750 \pm 448$ & $860 \pm 380$ \\
\hline & $\begin{array}{l}\text { Tank biomass } \\
(\mathrm{kg})\end{array}$ & 71.75 & 66.49 & 217.5 & 217.4 & 78.23 & 66.4 & 175.5 & 209 \\
\hline & $\begin{array}{l}\text { Subsystem } \\
\text { biomass (kg) }\end{array}$ & 573.14 & & & & 529.13 & & & \\
\hline & & Pond A & & & & Pond B & & & \\
\hline & & $\begin{array}{l}\text { Silver } \\
\text { carp }\end{array}$ & $\begin{array}{l}\text { Common } \\
\text { carp }\end{array}$ & $\begin{array}{l}\text { Common } \\
\text { nase }\end{array}$ & & $\begin{array}{l}\text { Silver } \\
\text { carp }\end{array}$ & $\begin{array}{l}\text { Common } \\
\text { carp }\end{array}$ & $\begin{array}{l}\text { Common } \\
\text { nase }\end{array}$ & \\
\hline Stocked & Stocking & & & & & & & & \\
\hline \multirow[t]{2}{*}{ fish } & $\begin{array}{l}\text { density (fish } \\
\mathrm{ha}^{-1} \text { ) }\end{array}$ & 213 & 1240 & 5464 & & 213 & 1240 & 5464 & \\
\hline & $\begin{array}{l}\text { Biomass } \\
\left(\mathrm{kg} \cdot \mathrm{ha}^{-1}\right)\end{array}$ & 246 & 450 & 55 & & 246 & 450 & 55 & \\
\hline \multirow{2}{*}{$\begin{array}{l}\text { Harvested } \\
\text { fish }\end{array}$} & Survival (\%) & 97 & 84 & 25 & & 97 & 95 & 68 & \\
\hline & $\begin{array}{l}\text { Biomass gain } \\
\left(\mathrm{kg} \cdot \mathrm{ha}^{-1}\right)\end{array}$ & 225.3 & 313.7 & -40.2 & & 346.9 & 417.2 & 15.2 & \\
\hline
\end{tabular}

Table 2

2.8. Changes in SGR and FCR values are shown in Fig. 3.

The sturgeon weight gain in system A was $400.4 \mathrm{~kg}$, while the amount of feed utilized was $812.4 \mathrm{~kg}$. In system B the fish gained $357 \mathrm{~kg}$ of biomass and consumed 798 $\mathrm{kg}$ of feed. The nitrogen load of the feed delivered to the ponds was about $320 \mathrm{~kg} \mathrm{ha}^{-1}$ (see Table 2).The final sturgeon survival rates in tanks 1, 2, 3, and 4 were $90 \%, 82 \%, 100 \%$, and $99 \%$ respectively, and in tanks 5, 6, 7, and 8 they were $88 \%, 83 \%, 94 \%$, and $97 \%$.

The total weight of the 191 carp harvested from pond A was $139.75 \mathrm{~kg}$. In pond $\mathrm{B}, 215$ fish were caught and their total weight was
Average seasonal hydrochemical parameters of water, amount of feed utilized, and nitrogen input from the feed

\begin{tabular}{|c|c|c|}
\hline & System A & System B \\
\hline & Tanks 1-4 & Tanks 5-8 \\
\hline$\overline{\mathrm{O}_{2}\left(\mathrm{mg} \mathrm{l}^{-1}\right)}$ & $5.93 \pm 0.57$ & $5.83 \pm 0.5$ \\
\hline $\mathrm{pH}$ & $7.39 \pm 0.03$ & $7.48 \pm 0.03$ \\
\hline Temp. $\left({ }^{\circ} \mathrm{C}\right)$ & $20.37 \pm 0.6$ & $20.94 \pm 0.4$ \\
\hline \multirow[t]{2}{*}{ Feed (kg) } & 812.4 & 798.8 \\
\hline & Pond A & Pond B \\
\hline TKN $\left(\mathrm{mg} \mathrm{l}^{-1}\right)$ & $1.73 \pm 0.73$ & $2.14 \pm 0.25$ \\
\hline $\mathrm{N}-\mathrm{NO}_{3}\left(\mathrm{mg} \mathrm{l}^{-1}\right)$ & $0.88 \pm 0.53$ & $0.49 \pm 0.49$ \\
\hline $\mathrm{N}-\mathrm{NO}_{2}\left(\mathrm{mg} \mathrm{l}^{-1}\right)$ & $0.006 \pm 0.0017$ & $0.0034 \pm 0.0029$ \\
\hline $\mathrm{N}-\mathrm{NH}_{4}\left(\mathrm{mg} \mathrm{l}^{-1}\right)$ & $0.24 \pm 0.12$ & $0.17 \pm 0.13$ \\
\hline $\mathrm{PO}_{4}\left(\mathrm{mg} \mathrm{l}^{-1}\right)$ & $0.15 \pm 0.12$ & $0.11 \pm 0.06$ \\
\hline $\mathrm{TP}\left(\mathrm{mg} \mathrm{l}^{-1}\right)$ & $0.35 \pm 0.08$ & $0.36 \pm 0.08$ \\
\hline Nitrogen input (kg/pond) & 58.6 & 57.6 \\
\hline Nitrogen input $\left(\mathrm{kg} \mathrm{ha}^{-1}\right)$ & 325.4 & 320.0 \\
\hline
\end{tabular}




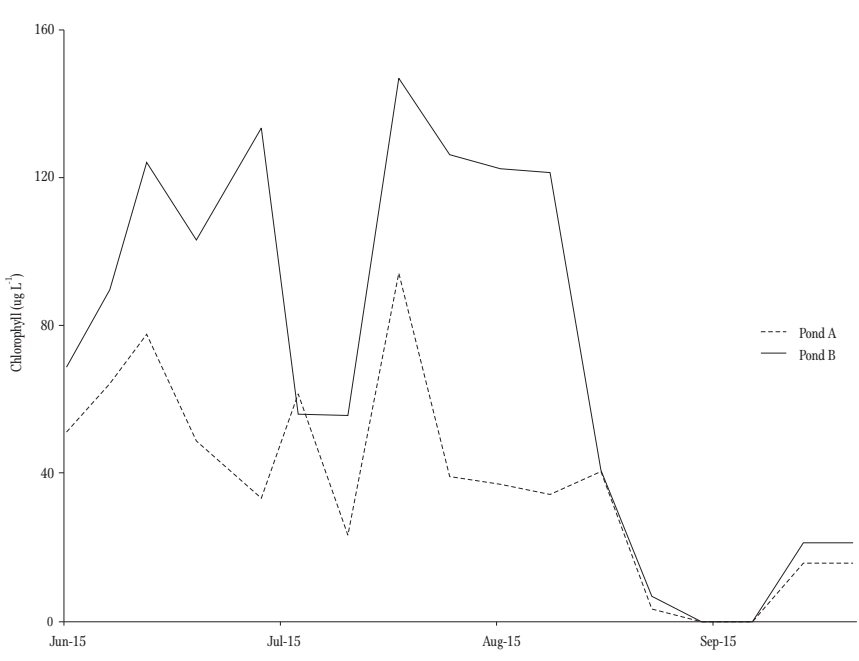

Figure 2. Chlorophyll content in the water of ponds A and B.
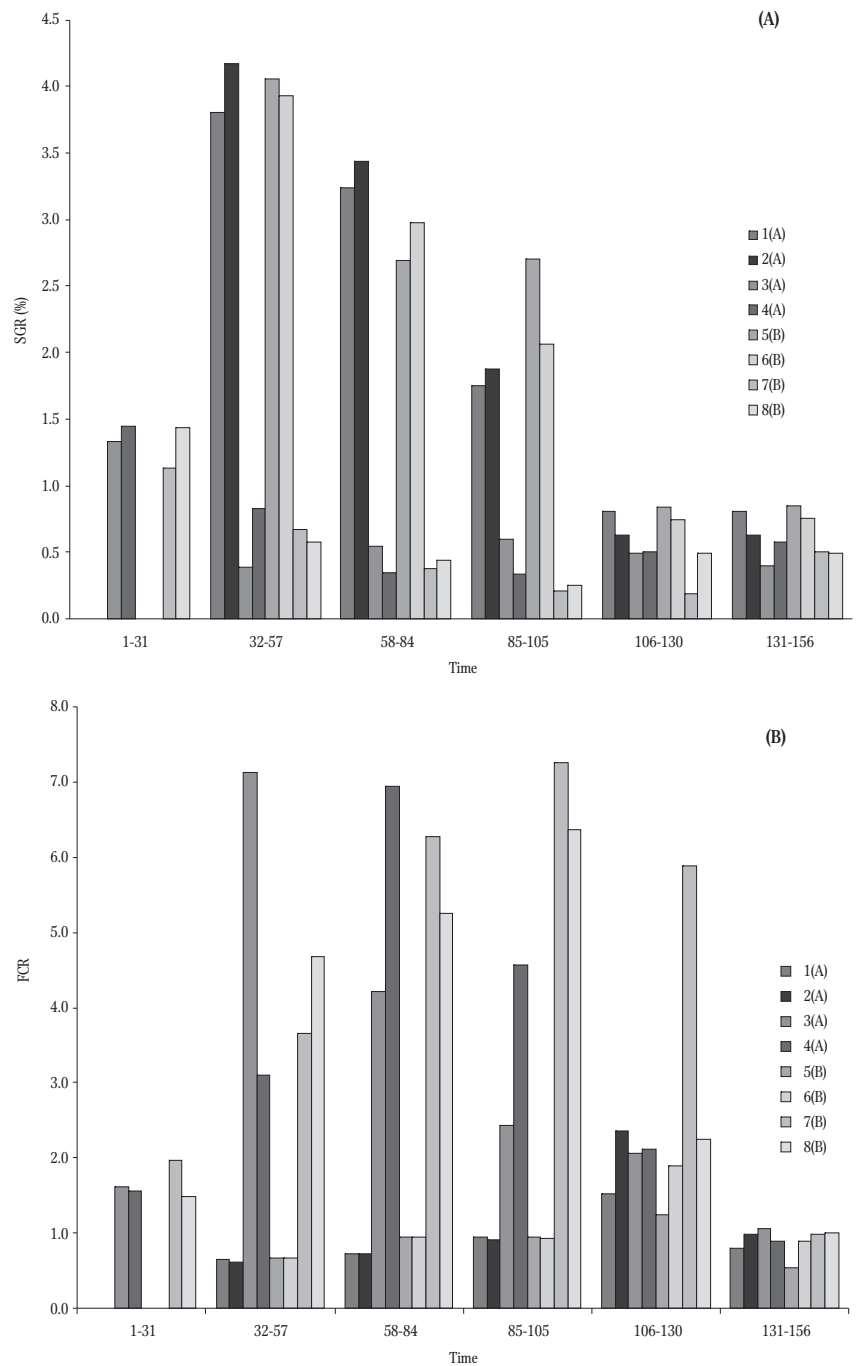

Figure 3. Values of (A) Specific Growth Rate (SGR) and (B) Food Conversion Ratio (FCR) of the fish in the tanks.
$158.7 \mathrm{~kg}$. Thirty-eight silver carp specimens were harvested from each pond at a total weight of 86.25 $\mathrm{kg}$ in pond $\mathrm{A}$ and $108.45 \mathrm{~kg}$ in pond $\mathrm{B}$. The number of common nase caught in pond A was 245 at a weight of $2.7 \mathrm{~kg}$, while in pond B 676 fish were caught at a total weight of $12.85 \mathrm{~kg}$. Data on fish yield in the extensive ponds is detailed in Table 1.

\section{Discussion}

We described observations of a real aquaculture unit, which we believe can be of interest to a very broad audience of fishery biologists. As a preface to the discussion, it should be stated that because applied treatments have no replications, we did not perform any statistical analysis.

The concentrations of nitrogen and phosphorus species measured and, most of all, the chlorophyll content indicated that the treatments applied in pond B had a positive affect on the water quality in system B. Of all the nutrients measured, the nitrogen load was the main factor that limited pond capacity (Hargraves 1998). Excessive fish production in the intensive unit expressed as the amount of feed utilized feed (protein was the main source of nitrogen) resulted in higher nutrient loads in the extensive pond, which affected water quality. According to Schneider et al. (2005), fish only retain about $30 \%$ of the nitrogen as biomass, while the rest is released into the water. Data obtained during the SustainAqua (2009) project suggested that the maximum nitrogen input into the extensive unit was $1.7-1.9 \mathrm{~g} \cdot \mathrm{m}^{2}$ per day. The protein content of the feed utilized in our monitoring was $45 \%$. Based on Schneider et al. (2005), for every kilogram of the feed used about $50 \mathrm{~g}$ of nitrogen was introduced into the water. The nutrient load changed along with the amount of feed utilized; however, because sturgeon yearlings were gaining weight more slowly than expected, feed utilization was underestimated. Therefore, the load of organic matter (fish waste, uneaten feed, metabolic products) released into the extensive units was 
relatively low. The nitrogen load did not exceeded $0.5 \mathrm{~g} \cdot \mathrm{m}^{2}$ per day for the major part of the rearing season. Therefore, the ammonia nitrogen content, $\mathrm{pH}$ values, and other water parameters measured did not exceed levels that were harmful to the fish in the ponds or the tanks.

The number of fish in each system was the same, hence the load of organic matter was similar and the potential inequalities resulting from the mortality of several fish can be disregarded. Therefore, the differences observed in water quality between the ponds was the result of the technological modifications applied (additional substrate for periphyton and carbohydrate supplementation). It is essential to explain that the substrate for periphyton provided an area equivalent to $13 \%$ of the pond surface, which was lower than in examples from the literature (Azim et al. 2004, Uddin et al. 2008, Gal et al. 2010). However, when combined with carbohydrate supplementation, these treatments effectively affected water quality. Therefore, in our observations we did not consider the separate effects of periphyton and methanol on water or fish parameters. Instead, we applied both treatments moderately in one pond to maintain costs at an optimal level.

\section{Fish in the extensive part of the system}

The yields obtained from the extensive ponds indicate the high growth potential of the fish and the natural productivity of these ecosystems when integrated with intensive aquaculture systems. According to Kestemont (1995), extensive carp rearing allows for fish production of $150-300 \mathrm{~kg} \cdot \mathrm{ha}^{-1}$ per year. When using fertilization, it is possible to increase production to $500-800 \mathrm{~kg} \cdot \mathrm{ha}^{-1}$ per year. We managed to produce 313.7 and $417.2 \mathrm{~kg} \cdot \mathrm{ha}^{-1}$ per year in ponds $\mathrm{A}$ and $\mathrm{B}$, respectively. The results indicate that post-production water with high nutrient loads effectively increased pond productivity without additional fertilization. Despite the fact that carp had no chance to directly utilize the matter flowing in from the intensive unit, the increase in biomass for the given pond surface area was higher than that recorded in similar ponds on the same fish farm. It should be noted that the carp in the extensive ponds had also an important technical function. In the farming model presented, the carp age range meant that presumably they would utilize both the benthos and the larger zooplankton forms. At the same time, carp unit weight was large enough to efficiently re-suspend bottom sediments, which accelerated the transfer of matter and biochemical changes in the pond ecosystem. However, the most important fact is that the treatments designed to improve hydrochemical conditions improved the efficiency of carp farming. In pond B, where additional treatments were applied, carp biomass gain was 25\% higher than in pond A. Carp survival in system B was also higher (10\%). This indicated that it was possible to improve not only productivity directly in the water but also in the supply of natural food for carp.

An essential aspect of properly designing the stocking of the extensive unit was the choice of additional fish species and age ranges of fish that have different food preferences from carp, such as Chinese carp. In our case, silver carp provided a filter feeder that utilizes species from lower levels of the food chain. The results of production of silver carp provide important information on the production capability of the systems described. The data proved how much the available food bases differed in ponds A and B. The increases in biomass and survival of this species were satisfactory in both ponds and much higher than in traditional earthen ponds. It was noteworthy that even though the survival of silver carp was identical in both ponds, the biomass in pond B was 54\% higher than in pond A. Again, this reflects the higher natural productivity and higher production capacity of system B, and it is directly associated with the treatments applied in pond B. The larger share of silver carp food is phytoplankton. Data on chlorophyll content show that phytoplankton was more abundant in pond B; therefore, silver carp growth performance was better in this pond. This concurs with studies by Avnimelech (1994), Azim and Little (2006), and Gal et al. (2010) that show that in favorable conditions unused nitrogen can be recycled and utilized by fish. 
Literature data indicate that periphyton can assimilate nutrients. Autotrophic periphyton use the mineral share of the nutrients, while heterotrophic organisms that live on the periphyton decompose the growing biomass into organic matter. This process alone is essential for the ecosystem since it accelerates decomposition compared to that in the midwaters or on pond bottoms. However, the main point of using periphyton in the integrated system is to retain in aquaculture products as much nutrient and waste matter as possible. Therefore, it is important to include in the extensive unit species of fish or other organisms of potential economic value that can build biomass using periphyton (Azim et al. 2003b). This is why common nase was tested in the present study. The result of its production is more evidence of the better productivity of pond $\mathrm{B}$. Common nase survival was $43 \%$ better and average unit weight was $80 \%$ higher in pond $\mathrm{B}$ than in pond $\mathrm{A}$. This indicated that the development of periphyton in pond A was poor, and the fish did not have enough food to survive. The example illustrates the great potential of periphyton utilization in integrated systems. However, the survival of the common nase was unsatisfactory in both ponds. The most probable reason for this was the predatory bird pressure and physical injury caused by pumps. Some individuals were found in the fish tanks indicating that the pumps should be covered to protect smaller organisms from being drawn into them.

\section{Fish in the intensive part of the system}

The sturgeon yearling growth rate must be analyzed separately from that of the fish fry. Even though the SGR values achieved would be sufficient in other production systems (carp ponds), they were not economically advantageous in the integrated systems studied. The reason for the unsatisfactory fish growth rates might have been the high biomass that these fish achieved, which, along with the number of fish per tank, exceeded $25 \mathrm{~kg} \cdot \mathrm{m}^{3}$ of water. This high fish density might have influenced growth rates since stocking density is one of the factors that affects the final results of fish rearing. High stocking density can lead to limited access to feed, body weight disparity among fish, and even cannibalism (Folkvord 1997, Fessehaye et al. 2006). Potthoff and Christman (2006) suggest that, in some cases, higher density can promote fish growth since increased competition for food also increases fish appetite. Nevertheless, as reported by Szczepkowski et al. (2011) and Jodun et al. (2002) in studies on Atlantic sturgeon (Acipenser oxyrinchus Mitchill) and by Rafatnezhad et al. (2008) in a study on beluga (Huso huso (L.)), average fish growth decreased as fish density increased, which concurs with our observations. The most probable reason is that the greater competition for feed and/or living space increased fish stress, and this affected their appetites negatively.

During the rearing season, the sturgeon fry achieved satisfactory growth that was similar to values reported in the literature (Koksal et al. 2000, Coada et al. 2011). The mean seasonal growth rate of $\sim 1.7 \%$ in the tanks of both systems was a good, satisfactory result. During the initial period of the season (days 1 to 31), sturgeon mortality was observed, but it did not exceed $12 \%$. It is possible that some fish did not prey on food properly because of stress from transport and stocking. According to Steffens et al. (1990), high mortality is frequently noted in young fish (under $30 \mathrm{~g}$ body weight), and in addition to weight gain, survival rates were better at high stocking densities. These observations were confirmed with the sturgeon yearlings, the survival rates of which were $100 \%$ (average in system A tanks) and 96\% (average in system B tanks), which were very good results. Slightly better results were noted in system A than in system B, in which brief technical problems occurred that resulted in high water temperatures and short periods of unfavorable water parameters (especially in tanks 7 and 8). Therefore, it was assumed that the technological modifications to the pond that resulted in different water parameters in the extensive part of system B did not affect the outcome of fish rearing in the intensive part of the integrated system either positively nor negatively.

Feeding schedules are an important factor that influences the profitability of fish rearing. Coada et al. (2011) and Luo et al. (2015) report that feeding 
hybrid sturgeon, (Acipenser schrenckii Brandt and A. baerii) in short intervals with smaller quantities of feed resulted in improved production at lower feed costs. Based on this information, we started feeding in the early morning and extended it using an automatic feed dosing system. This resulted in a favorable fish fry FCR; however, based on data from the previous season (not included), the sturgeon yearlings were fed higher feed doses than those calculated to eliminate this possible cause of declines in weight gain. Therefore, the average FCR of 2.8 for yearling fish was unfavorable and worse than that recorded by Jodun et al. (2002) in a study of Atlantic sturgeon of similar weight, rearing density, and feeding rate. We assumed that the growth of the fish throughout the system depended on the amount of feed delivered in the intensive part of it. This relationship illustrated the system nutrient budget. The profitability of fish production depends on the FCR value, which is why the overall weight gain of the fish in the whole system was calculated. The FCR for system A was 1.9, and for system B it was 1.89. Feed application should be more controlled in profitable fish production.

The intensive-extensive aquaculture system described was the first of its kind to be operated to this extent in Poland. Fish rearing was carried out under actual environmental conditions using real aquaculture facilities. The data obtained confirmed the possibility of rearing sturgeon in an integrated system based on an earthen pond. The tank water parameters during the season allowed for sufficient fish growth. The additional treatments applied in pond B did not result in differences in fish yield between systems $\mathrm{A}$ and $\mathrm{B}$, but fish production in the extensive part of system B was higher. While providing additional substrates for periphyton growth did not require any significant investment, supplementing with organic carbon was a considerable expense. Another possibility for reducing costs is to utilize another carbon source that is cheaper than the one we used in this study. The combination of these two treatments was an efficient way to reduce ammonia nitrogen when there was a high load of feed and fish biomass.
Acknowledgments. The authors would like to thank Dénes Gál for his advice and discussions on this topic, which are appreciated. This work was supported by the National Centre for Research and Development, project Integr Aqua, No. PBS1/A8/6/2012.

Author contributions. M.P. conceived the research objectives; M.P., L.K., M.I. designed the experiment; M.P., L.K., M.I., B.S., J.S. performed field research; M.P., L.K. analyzed the data; L.K. wrote the paper; M.P. supervised the project.

\section{References}

Asaduzzman M., Wahab M., Verdegem M., Huque S., Salam M., Azim M.E. 2008 - C/N ratio control and substrate addition for periphyton development jointly enhance freshwater prawn Macrobrachium rosenbergii production in ponds - Aquaculture 280: 117-123.

Avnimelech Y. 1999 - Carbon/nitrogen ratio as a control element on aquaculture systems - Aquaculture 176: 227-235.

Avnimelech Y., Kochva M., Diab S. 1994 - Development of controlled intensive aquaculture systems with a limited water exchange and adjusted carbon to nitrogen ratio Isr. J. Aquacult.-Bamid. 46: 119-131.

Azim M.E. 2001 - The potential of periphyton-based aquaculture production systems - Ph.D. thesis, Wageningen University.

Azim M.E., Verdegem M.C.J., Singh M., van Dam A.A., Beveridge M.C.M. 2003b - The effects of periphyton substrate and fish stocking density on water quality, phytoplankton, periphyton and fish growth - Aquac. Res. 34: 685-695.

Azim M.E., Little D.C. 2006 - Intensifying aquaculture production through new approaches to manipulating natural food - Perspectives in Aquaculture, Veterinary Science, Nutrition and Natural Resources, 1, No. 062.

Azim M.E., Milstein A., Wahab M.A., Verdegem M.C.J. 2003a - Periphyton-water quality relationships in fertilized fishponds with artificial substrates - Aquaculture 228: 169-187.

Azim M.E., Wahab M.A., Verdegem M.C.J., van Dam A.A., van Rooij J.M., Beveridge M.C.M. 2002 - The effects of artificial substrates on freshwater pond productivity and water quality and the implications for periphyton-based aquaculture - Aquat. Living Resour. 15: 231-241.

Azim M.E., Wahab M.A, Biswas P.K., Asaeda T. Fujino T., Verdegem M.C.J. 2004 - The effect of periphyton substrate density on production in freshwater polyculture ponds - Aquaculture 232: 441-453. 
Brune D.E., Schwartz G., Eversole A.G., Collier J.A., Schwedler T.E. 2003 - Intensification of pond aquaculture and high rate photosynthetic systems Aquacult. Eng. 28: 65-86.

Clesceri L.S., Greenberg A.E., Eaton A.D. 1998 - Standard methods for the examination of water and wastewater, $20^{\text {th }}$ edition - APHA.

Coada M.T., Cristea V., Patriche N., Patriche T., Raduta R., Bocioc E., Ion S. 2011 - Preliminary results on growth of juvenile sturgeon (Acipenser gueldenstaedti Brandt \& Ratzeburg, 1833) in open aquaculture systems - J. Environ. Prot. Ecol. 12: 1910-1913.

Crab R., Avnimelech Y., Defoirdt T., Bossier P., Verstraete W. 2007 - Nitrogen removal techniques in aquaculture for sustainable production - Aquaculture 270: 1-14.

Fassehaye Y., Kabir A., Bovenhuis H., Komen H. 2006 - Prediction of cannibalism in juvenile Oreochromis niloticus based on predator to prey weight ratio, and effects of age and stocking density - Aquaculture 255: 314-322.

Folkvord A. 1997 - Ontogeny of cannibalism in larval and juvenile fishes with special emphasis on Atlantic cod - In: Early life history and recruitment in fish populations (Eds) R. C. Chambers, E.A. Trippel, Chapman \& Hall, London: 335-366.

Gal D., Kerepeczki E., Kosaros T., Pekar F. 2010 - Nutrient reusing capacity of a combined pond aquaculture system - AACL Bioflux 3: 373-377.

Hargraves J.A. 1998 - Nitrogen biogeochemistry of aquaculture ponds - Aquaculture 166: 181-212.

Hermanowicz W., Dożańska W., Dojlido J., Koziorowski B. 1976 - Physicochemical water and wastewater analysis Arkady, Warszawa: 133-136 (in Polish).

Jodun W.A., Milard M.A., Mohler J. 2002 - The effect of rearing density on growth, survival, and feed conversion of juvenile Atlantic sturgeon - N. Am. J. Aquacult. 64: 10-15.

Kestemont P. 1995 - Different systems of carp production and their impacts on the environment - Aquaculture 129: 347-372.

Koksal G., Rad F., Kindir M. 2000 - Growth performance and feed conversion efficiency of Siberian Sturgeon juveniles (Acipenser baeri) reared in concrete raceways - Turk. J. Vet. Anim. Sci. 24: 435-442.
Liu J.X., Cai Q. 1998 - Integrated aquaculture in Chinese lakes and paddy fields - Ecol. Eng. 11: 48-59.

Luo L., Li T., Xing W., Xue M., Ma Z., Jiang N., Li W. 2015 Effects of feeding rates and feeding frequency on the growth performances of juvenile hybrid sturgeon, Acipenser schrenckii Brandt $9 \times A$. baeri Brandto ${ }^{\pi}-$ Aquaculture 448: 229-233.

Playchoom C., Pungrasmi W., Powtongsook S. 2011 - Effect of carbon sources and carbon/nitrogen ratio on nitrate removal in aquaculture denitrification tank - IPCBEE, vol. 1, IACSIT Press, Singapore.

Potthoff M.T., Christman M.C. 2006 - Growth depensation and group behavior in juvenile hybrid striped bass Morone chrsops $\times$ Morone saxatilis: effects of group membership, feeding method, ration size and size disparity - J. Fish Biol. 69: 828-845.

Rafatnezhad S., Falahatkar B., Gilani M.H.T. 2008 - Effects of stocking density on haematological parameters, growth and fin erosion of great sturgeon (Huso huso) juveniles Aquac. Res. 39: 1506-1513.

Schneider O., Sereti V., Eding E., Vedrreth J. 2005 - Analysis of nutrient flows in integrated intensive aquaculture systems - Aquacult. Eng. 32: 379-401.

Steffens W., Jahnichen H., Fredrich F. 1990 - Possibilities of sturgeon culture in Central Europe - Aquaculture 89: 101-122.

SustainAqua 2009 - Evaluation report about pre-existing knowledge related to the site Hungary, including a review about market potential, nutrient uptake and cultivation efficiency of chosen crops - Delivebate SustainAqua. Integrated approach for a sustainable and healthy freshwater aquaculture.

Szczepkowski M., Szczepkowska B., Piotrowska I. 2011 Impact of higher stocking density of juvenile Atlantic sturgeon, Acipenser oxyrinchus Mitchill, on fish growth, oxygen, consumption, and ammonia excretion - Arch. Pol. Fish. 19: 59-67.

Uddin M.S, Milsten A., Azim M.E., Wahab M.A., Verdegem M., Verreth J. 2008 - Effects of stocking density, periphyton substrate and supplemental feed on biological processes affecting water quality in earthen tilapia-prawn polyculture ponds - Aquac. Res. 39: 1243-1257. 